\title{
Preliminary data of the scuttle flies (Diptera: Phoridae) in the linden-oak- hornbeam forest of the Wigry National Park, North East Poland
}

\author{
Ewa DURSKA \\ Museum and Institute of Zoology, Polish Academy of Sciences, Wilcza 64, 00-679 Warsaw, Poland, \\ edurska@miiz.waw.pl
}

\begin{abstract}
Faunistic data on 66 species of geophilous scuttle flies cought by emergence traps placed in 6 sites of the linden-oak-hornbeam forest in the Wigry National Park in summer season of 2017 and 2018 are presented. About $60 \%$ of the individuals captured each year were species with at least 10 individuals. The same four dominants: Megaselia pulicaria-complex, M. flava, M. abdita and Gymnophora arcuata reached the highest abundance in the compared communities during both study seasons. Species with known biology accounted for only half of the captured species, but among them the most numerous (82\%) were species whose larvae were classified as sapro-/necro- and mycophagous.
\end{abstract}

Key words: Phoridae, linden-oak-hornbeam plots, emergence traps, Wigry National Park

\section{INTRODUCTION}

Phoridae are usually dark brown or black small flies, with body size from 1.0 to $5.5 \mathrm{~mm}$ for most species. They are one of the most abundant families of Diptera in woodland, meadow, agroecosystem and urban habitats. Scuttle flies, due to their highly diversified life cycles and environmental requirements, as well as relatively high number of species, can be useful in ecological studies (Disney \& Durska 2008; Durska 2013, 2015a).

To date, over 4000 species have been described, and one-fourth of these occur in the Palaearctic Region. The most abundant in species is the genus Megaselia - about 1500 described species. So far, 359 Phoridae species that have been shown from Poland (Disney 1991; Disney \& Durska 1998, 2011, 2014, 2017, 2020). Faunistic data on scuttle fly community in the Wigry National Park are presented for the first time.

The first collected data allowed to describe 8 species new to sciences (Disney \& Durska 2017, 2020). Currently, the composition of the Phoridae groups breeding in the soil of the hail environments of the WNP was discussed based on data from 2017/18.

\section{MATERIALS AND METHODS}

The study is based on the material collected in the Wigry National Park (WNP), the northeastern edge of Augustów Forest, which is a large forest complex in NE Poland $\left(54^{\circ} 01^{\prime} \mathrm{N} 23^{\circ} 05^{\prime}\right.$ E). The main forested area of the Park is covered by the association of sub-continental lindenoak-hornbeam wood (Tilio-Carpinetum). The scuttle flies were collected using emergence traps (Durska 2015b), on six linden-oak-hornbeam plots, all in Sobolewo environs:

- Stand 1 - Tilio-Carpinetum calamagrostietosum typicum, 540.1'57"N, 2259'34"E, $167 \mathrm{~m}$ a.s.1, forest district 92d;

- Stand 4a - Tilio-Carpinetum calamagrostietosum typicum, 5401'51"N, 2301'27"E, $154 \mathrm{~m}$ a.s.1., forest district $127 \mathrm{c}$;

- Stand 4b - Tilio-Carpinetum typicum, 540 $01^{\prime} 56^{\prime \prime} \mathrm{N}, 23^{\circ} 00^{\prime} 55^{\prime \prime} \mathrm{E}, 154 \mathrm{~m}$ a.s.l. forest district $116 \mathrm{f}$;

- Stand 4c-Tilio-Carpinetum calamagrostietosum typicum, 5401'53"N, 2301'06"E, $153 \mathrm{~m}$ a.s.1., forest district $116 \mathrm{~g}$; 
- Stand 5 - Tilio-Carpinetum typicum, $5^{\circ} 04^{\prime} 23^{\prime \prime} \mathrm{N}, 23^{\circ} 00^{\prime} 55^{\prime \prime} \mathrm{E}, 149 \mathrm{~m}$ a.s.l., forest district 52c;

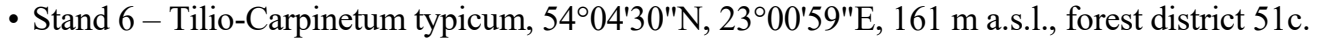

Three emergence traps were deployed in each of the six plots in 2017 (from 23th May to 8th September) and 2018 (from 29th May to 24th September ) (Fig. $1)$.

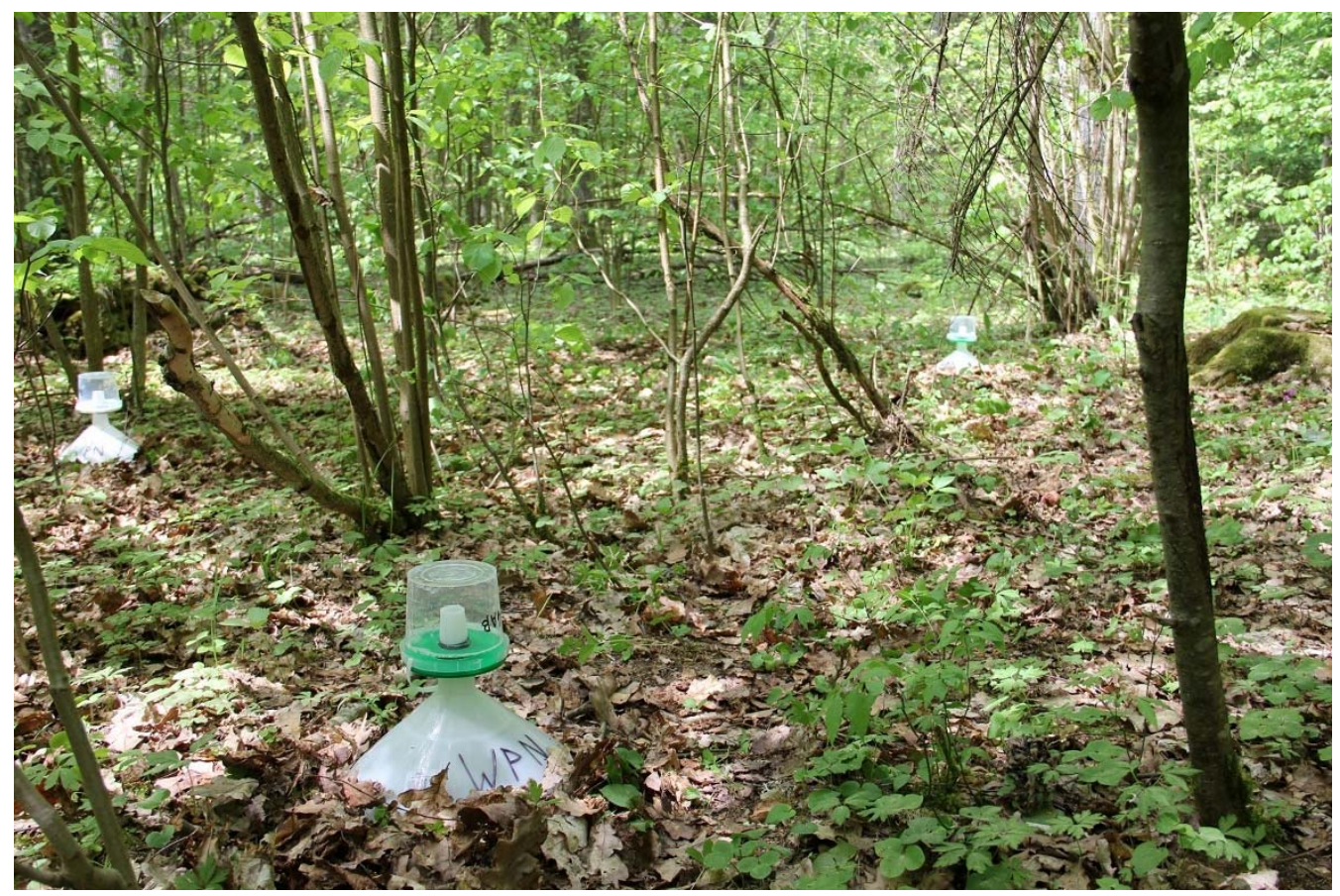

Fig. 1. The emergence traps placed on the stand 4B (fot. A. Leidel).

The collected material of Phoridae were identified using a microscope (Leica) and then placed in the tubes with alcohol. The identified material is deposited in the collection of Museum and Institute of Zology PAS in Warsaw and in the University of Cambridge Museum of Zoology (UCMZ).

\section{RESULTS}

During the two years study (2017 and 2018), using emergence traps, were collected 1021 scuttle fly individuals $(2017: \mathrm{N}=607,2018: \mathrm{N}=414)$, represented by 66 identified species (Table 1). The male-to-female sex ratio reached 5.19.

On six oak-hornbeam plots 53 scuttle fly species (plus Megaselia sp. 'A' and Megaselia sp. 'B') were identified in 2017. The following thirteen species were the dominants (abundance $\geq$ 10 individuals): $M$. pulicaria-complex $(\mathrm{N}=110), M$. flava $(\mathrm{N}=63), M$. abdita $(\mathrm{N}=49)$, Gymnophora arcuata $(\mathrm{N}=30)$, M. lata $(\mathrm{N}=27)$, M. campestris $(\mathrm{N}=16), M$. sornectergata $(\mathrm{N}$ =16), $M$. flavicans $(\mathrm{N}=14), M$. meconicera $(\mathrm{N}=14)$, M. obscuripennis $(\mathrm{N}=13), M$. giraudiicomplex $(\mathrm{N}=11), M$. fumata $(\mathrm{N}=10)$ and $M$. zonata $(\mathrm{N}=10)$. The total abundance of these dominant species $(\mathrm{N}=383)$ accounted over $63 \%$ of the scuttle fly community. 
Table 1. Phoridae found in the linden-oak-hornbeam forest of the Wigry National Park. Dominant species, at least at one site of the habitat types ( $x x \geq 10$ individuals; $x x x \geq 100$ individuals), are shown in bold type; * - species whose locus typicus relates to the sites studied (Disney \& Durska 2017, 2020); ${ }^{\text {a }}$ - probable trophic group of larvae.

\begin{tabular}{|c|c|c|c|c|}
\hline No & Species & 2017 & 2018 & Larval diet \\
\hline 1 & Conicera floricola Schmitz & - & $\mathrm{xx}$ & sapropagous \\
\hline 2 & Gymnophora arcuata (Meigen) & $\mathrm{xx}$ & $\mathrm{xx}$ & unknown \\
\hline 3 & Gymnophora quartomollis Schmitz & - & $\mathrm{xx}$ & unknown \\
\hline 4 & Megaselia abdita Schmitz & $\mathrm{xx}$ & $\mathrm{xx}$ & necrophagous \\
\hline 5 & Megaselia aculeata (Schmitz) & $\mathrm{x}$ & $\mathrm{x}$ & unknown \\
\hline 6 & *Megaselia aliusalius Disney & $\mathrm{x}$ & & unknown \\
\hline 7 & Megaselia altifrons (Wood) & $\mathrm{x}$ & $\mathrm{x}$ & ${ }^{\mathrm{a}}$ saprophagous \\
\hline 8 & Megaselia angusta (Wood) & $\mathrm{x}$ & - & unknown \\
\hline 9 & Megaselia bovista (Gimmerthal) & $\mathrm{x}$ & $\mathrm{x}$ & mycophagous \\
\hline 10 & Megaselia brevicostalis (Wood) & $\mathbf{x}$ & & polysaprophagous \\
\hline 11 & Megaselia campestris (Wood) & $\mathrm{xx}$ & $\mathrm{x}$ & unknown \\
\hline 12 & Megaselia ciliata (Zetterstedt) & $\mathrm{x}$ & - & zoophagous \\
\hline 13 & Megaselia citrinella Buck & & $\mathrm{x}$ & unknown \\
\hline 14 & Megaselia dahli (Becker) & - & $\mathrm{xx}$ & unknown \\
\hline 15 & Megaselia dimidia Schmitz & $\mathrm{x}$ & & unknown \\
\hline 16 & Megaselia diversa (Wood) & $\mathrm{x}$ & & ${ }^{\mathrm{a}}$ sapropagous \\
\hline 17 & Megaselia elongata (Wood) & $\mathrm{x}$ & $\mathrm{xx}$ & zoophagous \\
\hline 18 & *Megaselia sp. exwignatpark Disney & $\mathrm{x}$ & & unknown \\
\hline 19 & Megaselia flava (Fallén) & $\mathrm{xx}$ & $\mathrm{xx}$ & mycophagous \\
\hline 20 & Megaselia flavescens (Wood) & $\mathrm{x}$ & & unknown \\
\hline 21 & Megaselia flavicans Schmitz & $\mathrm{xx}$ & $\mathrm{x}$ & unknown \\
\hline 22 & Megaselia flavicoxa (Zetterstedt) & $\mathrm{x}$ & $\mathrm{xx}$ & zoophagous \\
\hline 23 & Megaselia frameata Schmitz & $\mathrm{x}$ & $\mathrm{x}$ & mycophagous \\
\hline 24 & Megaselia fumata (Malloch) & $\mathrm{xx}$ & $\mathrm{x}$ & unknown \\
\hline 25 & Megaselia fusca (Wood) & $\mathrm{x}$ & - & ${ }^{\mathrm{a}}$ saprophagous \\
\hline 26 & Megaselia fuscovariana (Schmitz) & $\mathrm{x}$ & - & unknown \\
\hline 27 & Megaselia giraudii-complex & $\mathrm{xx}$ & $\mathrm{x}$ & polysaprophagous \\
\hline 28 & Megaselia gregaria (Wood0 & $\mathrm{x}$ & - & unknown \\
\hline 29 & Megaselia halterata (Wood0 & $\mathrm{x}$ & $\mathrm{x}$ & mycophagous \\
\hline 30 & Megaselia hirsuta(Woodo & $\mathrm{x}$ & - & unknown \\
\hline 31 & Megaselia ignobilis (Schmitz) & $\mathrm{x}$ & $\mathrm{xx}$ & unknown \\
\hline 32 & Megaselia involuta (Wood) & - & $\mathrm{x}$ & unknown \\
\hline 33 & Megaselia lata (Wood) & $\mathrm{xx}$ & $\mathrm{x}$ & mycophagous \\
\hline 34 & Megaselia latifrons (Wood) & $\mathrm{x}$ & $\mathrm{x}$ & unknown \\
\hline 35 & Megaselia longicostalis (Wood) & $\mathrm{x}$ & $\mathrm{x}$ & necrophagous \\
\hline 36 & Megaselia lutea (Meigen) & $\mathrm{x}$ & - & mycophagous \\
\hline 37 & Megaselia major (Wood0 & $\mathrm{x}$ & & unknown \\
\hline 38 & Megaselia meconicera (Speiser) & $\mathrm{xx}$ & $\mathrm{x}$ & a saprophagous \\
\hline 39 & Megaselia minor (Zetterstedt) & $\mathrm{x}$ & - & necrophagous \\
\hline 40 & Megaselia nasoni (Malloch) & - & $\mathrm{x}$ & zoophagous \\
\hline 41 & Megaselia nigra (Meigen) & 1 & & mycophagous \\
\hline 42 & Megaselia obscuripennis (Wood) & $\mathrm{xx}$ & 5 & zoophagous \\
\hline 43 & Megaselia picta (Lehmann) & - & $\mathrm{x}$ & unknown \\
\hline 44 & *Megaselia sp. pilusdepilata Disney & $\mathrm{x}$ & & unknown \\
\hline
\end{tabular}


Continuation of the Table 1

\begin{tabular}{lllll}
\hline No & Species & 2017 & 2018 & Larval diet \\
\hline 45 & Megaselia pleuralis (Wood) & $\mathrm{x}$ & - & polysaprophagous \\
46 & *Megaselia polonici Disney & - & $\mathrm{x}$ & unknown \\
47 & Megaselia propingua (Wood) & $\mathrm{x}$ & $\mathrm{x}$ & unknown \\
48 & Megaselia pulicaria-complex & $\mathrm{xxx}$ & $\mathrm{xx}$ & polysaprophagous \\
49 & Megaselia pumila (Meigen) & $\mathrm{x}$ & $\mathrm{x}$ & mycophagous \\
50 & Megaselia pusilla (Meigen) & $\mathrm{x}$ & $\mathrm{x}$ & saprophagous \\
51 & *Megaselia quasirufifrons Disney & $\mathrm{x}$ & & unknown \\
52 & *Megaselia reduncus Disney & - & $\mathrm{x}$ & unknown \\
53 & Megaselia rubella (Schmitz) & $\mathrm{x}$ & $\mathrm{x}$ & mycophagous \\
54 & Megaselia ruficornis (Meigen) & $\mathrm{x}$ & - & saprophagous \\
55 & Megaselia rufipes (Meigen0 & - & $\mathrm{x}$ & polysaprophagous \\
56 & Megaselia scutellaris (Wood0 & $\mathrm{x}$ & $\mathrm{x}$ & mycophagous \\
57 & *Megaselia setaeneclobi Disney & $\mathrm{x}$ & & unknown \\
58 & Megaselia sornectergata Disney & $\mathrm{xx}$ & $\mathrm{x}$ & unknown \\
59 & Megaselia subnudipennis (Schmitz) & - & $\mathrm{x}$ & necrophagous \\
60 & Megaselia sulphuripes (Meigen) & $\mathrm{x}$ & - & unknown \\
61 & Megaselia sylvatica (Wood0 & $\mathrm{x}$ & $\mathrm{x}$ & mycophagous \\
62 & Megaselia unicolor (Schmitz) & $\mathrm{x}$ & $\mathrm{x}$ & a saprophagous \\
63 & Megaselia verralli (Wood) & $\mathrm{x}$ & $\mathrm{x}$ & unknown \\
64 & *Megaselia wigryensis Disney & - & $\mathrm{x}$ & unknown \\
65 & Megaselia zonata (Zetterstedt) & $\mathrm{xx}$ & $\mathrm{x}$ & unknown \\
- & Megaselia sp. A & $\mathrm{x}$ & & unknown \\
- & Megaselia sp. B & $\mathrm{x}$ & $\mathrm{xx}$ & unknown \\
- & Megaselia sp. males & $\mathrm{xx}$ & - \\
- & Megaselia sp. females & $\mathrm{x}$ & $\mathrm{x}$ & zoophagous \\
\hline 66 & Triphleba lugubris (Meigen) & &
\end{tabular}

In the collected material, on the same six plots, 44 scuttle fly species were identified in 2018 , among which the largest numbers reached ten dominant species (abundance $\geq 10$ individuals): M. pulicaria-complex $(\mathrm{N}=57)$, M. flava $(\mathrm{N}=31)$, Gymnophora quartomollis $(\mathrm{N}=26), G$. arcuata $(\mathrm{N}=24), M$. dahli $(\mathrm{N}=23)$, M. flavicoxa $(\mathrm{N}=21)$, M. ignobilis $(\mathrm{N}=20), M$. abdita $(\mathrm{N}$ $=15)$, Conicera floricola $(\mathrm{N}=12)$ and $M$. elongata $(\mathrm{N}=10)$. The dominants $(\mathrm{N}=239)$ accounted almost $58 \%$ of the phorid community.

The scuttle fly species, with a known biology (or probably known biology), accounted for over $51 \%(\mathrm{~S}=34)$ of the compared species. Among them, the most numerous group $(\mathrm{S}=28)$ were species with the sapro-/necro- and mycophagous larvae (over $82 \%$ ). The rest group consisted of six species with zoophagous larvae (Megaselia ciliata - facultative parasitoid of slugs: Arion sp., Deroceras sp., Megaselia elongata - facultative parasitoid of Julidae, Megaselia flavicoxa and Megaselia obscuripennis - parasitoid of Sciaridae, Megaselia nasoni prey on spider eggs, and Triphleba lugubris - parasitoid of queen pupae of Vespidae).

The differences in the number of species found on the plots in 2017 ranged from four to forty species. Whereas in 2018, differences in the number of species found on particular plots were small, from fourteen to nineteen species. 


\section{COMMENTS}

During the study on Phoridae in Wigry National Park in 2017 and 2018, conducted on the six plots, 1021 specimens were collected, represented by 66 species, among them eight species from the genus Megaselia were described as new to science in 2017 and 2020 (Table 1) (Disney \& Durska 2017, 2020).

The same four dominants: M. pulicaria-complex, M. flava, M. abdita and Gymnophora arcuata was found in both comparable communities (Table 1).

The most of the scuttle fly species found on the plots are common species with wide range of occurrence, but among the dominants $M$. sornectergata is the species new to the Polish fauna (Table 1) (Disney 1991; Durska 2013, 2015a; Disney \& Durska 2020).

The male-to-female sex ratio using the emergence trap method reached 5.19, in contrast to data obtained using yellow plastic pans from habitats after fire (sex ratio: 0.13) (Durska 2015a). It is worth adding that the sex ratios of Phoridae obtained in field collection, compared to those from rearings, are often dominated by one sex (Disney 1994). Based on the above data, it can be concluded that the differences in sex ratios obtained in these studies are related not only to the behaviour between the sexes, but also to the trapping method (Disney 1994, Durska et al. 2010, Durska 2013, Prescher et al. 2002).

It could be assumed, that the lower species richness and lower abundance of Phoridae species found in the 2018 samples compared to 2017 may be associated with exceptionally high temperature and low rainfall in 2018.

\section{ACKNOWLEDGEMENTS}

Ewa Durska's studies on Phoridae were carried out within the framework of the project: 'The influence of Impatiens parviflora on the species diversity of selected organisms and the forest environment of the Wigry National Park', co-financed from the forest fund under the agreement concluded between the State Forests National Forest Holding and the Wigry National Park (EZ.0290.1.36.2018 - Action No 7).

\section{REFERENCES}

Disney R. H. L. 1991. Family Phoridae. In: Soós A. and PAPP L. (ed.), Catalogue of Palaearctic Diptera. Vol. 7 (Dolichopodidae - Platypezidae). Pp. 143-204. Akademia Kiadó, Budapest.

DisNEY R. H. L. 1994: Scuttle flies: The Phoridae. Chapman and Hall, London. 467 pp.

DiSNEY R. H. L. \& DuRSKA E. 1998. A new genus and species of Phoridae (Diptera) from Poland. European Journal of Entomology 95: 437-453.

DiSNEY R. H. L. \& DURSKA E. 2008. Conservation evaluation and the choice of faunal taxa to sample. Biodiversity Conservation 17:449-451.

DiSNEY R. H. L. \& DURSKA E. 2011. Five new species and three new records of Megaselia Rondani (Diptera: Phoridae) from Pisz Forest (Poland). Annales Zoologici 61 (3): 527-534.

DiSNEY R. H. L. \& DURSKA E. 2014. A new species of Megaselia Rondani (Diptera: Phoridae) and two newly found species from Poland. Fragmenta Faunistica 57(1): 63-66.

Disney R. H. L. \& Durska E. 2017. Two new species of Megaselia Rondani (Diptera: Phoridae) from Poland. Fragmenta Faunistica 60(1): 47-52.

DisNeY R. H. L. \& DURSKA E. 2020. New species and new records of Megaselia Rondani (Insecta: Diptera: Phoridae) from Wigry National Park (Poland). Annales Zoologici 70(1): 97-108.

DURSKA E. 2013. Effects of disturbances on scuttle flies (Diptera: Phoridae) in Pine Forests. Biodiversity and Conservation 22: 1991-2021.

DURSKA E. 2015a. Effects of fire on scuttle flies (Diptera: Phoridae) in a pine forest in Poland. Entomologica Fennica 26: 181-193.

DURSKA E. 2015b. Zadrowate (Diptera: Phoridae) pożarzysk leśnych zebrane za pomocą pułapek naziemnych FLYTRAP 2014. ISSN 1895-4464; Dipteron 31: 17-20.

DuRsKa E., Bonet J. \& VIKLund B. 2010. The scuttle fly (Diptera: Phoridae) assemblages of a wildfire-affected hemiboreal old-growth forest in Tyresta (Sweden). Entomologica Fennica 21: 19-32. 
Prescher S., Moretti M. \& Duelli P. 2002. Scuttle flies (Diptera, Phoridae) in Castanea sativa forests in the southern Alps (Ticino, Switzerland), with thirteen species new to Switzerland. Mitteilungen der Schweizerischen entomologischen Gesellschaft 75: 289-298.

\section{STRESZCZENIE}

[Wstępne dane dotyczące zadrowatych (Diptera: Phoridae) lasu lipowo-grądowego w Wigierskim Parku Narodowym]

$\mathrm{W}$ pracy przedstawiono pierwsze dane o zadrowatych (Diptera: Phoridae) wykazanych z lasów lipowo-grądowych Wigierskiego Parku Narodowego. W materiale Phoridae, zebranym w letnich sezonach roku 2017 i 2018 metodą pułapek naziemnych rozstawionych na sześciu stanowiskach, stwierdzonych zostało 66 gatunków zadrowatych, w tym osiem gatunków zostało stąd wykazanych jako nowe dla nauki. Ponad 60 \% wszystkich osobników należało do gatunków zebranych w liczebnościach powyżej 10 osobników. W porównywanych zgrupowaniach obu badanych sezonów stwierdzono te same cztery dominanty, $\mathrm{tj}$. Megaselia pulicaria-complex, $M$. flava, M. abdita i Gymnophora arcuate. Gatunki o znanej biologii stanowią zaledwie połowę stwierdzonych tu gatunków, jednakże wśród nich najliczniej reprezentowane (82\% osobników) były gatunki, których larwy są zaklasyfikowane jako sapro-/nekro- i mykofagi. 